\title{
The Evolution of the Concept of International Peace and Security in light of UN Security Council Practice (End of the Cold War-Until Now)
}

\author{
Rasool Soltani, Maryam Moradi \\ Department of Law, Qeshm International Branch, Islamic Azad University, Qeshm, Iran \\ Email: rasoolsoltani@yahoo.com,maryam.moradi@iauqeshm.ac.ir
}

How to cite this paper: Soltani, R., \& Moradi, M. (2017). The Evolution of the Concept of International Peace and Security in light of UN Security Council Practice (End of the Cold War-Until Now). Open Journal of Political Science, 7, 133-144.

http://dx.doi.org/10.4236/ojps.2017.71010

Received: November 12, 2016 Accepted: December 31, 2016

Published: January 3, 2017

Copyright $\odot 2017$ by authors and Scientific Research Publishing Inc. This work is licensed under the Creative Commons Attribution International License (CC BY 4.0).

http://creativecommons.org/licenses/by/4.0/ (c) (i) Open Access

\begin{abstract}
With the start of globalization and the third millennium, international peace and security have gradually lost their traditional westphalian notion and have become complicated. The nature of threats against international peace and security has also spread to political, economical, social and environmental aspects as well as military ones. Therefore, it is not just governments who are responsible for establishing international peace and security; rather all the actors of the international system including individuals and major international bodies have their own share in bringing about peace and security. In this regard, UN Security Council, which is the most significant pillar of UN and guardian of international peace and security, has faced multiple challenges during its lifetime. During the Cold War and due to the competition between west and east superpowers, this council has proved principally impotent in encountering international crises. When the Cold War came to an end and the Soviet Union collapsed, there had been offered a great chance to the council to analyze international affairs with a new approach. The evolution of international peace and security notion and new interpretations of threats are the most manifested matters of the council in the post-Cold War era. This has proceeded to an extend that sometimes finding a legal status for the measures of the UN Security Council is difficult and the council has become sort of a legislator in the world. The most important issues that were addressed in the Council regarding international peace and security in post-Cold War era have been human rights violations, humanitarian law, terrorism, proliferation of mass destruction weapons and environmental problems. Expanding the Council's authorities should be based on a clear and general interpretation of them in the framework of the principles of the UN Charter. Consequently, the Security Council is not legally capable of doing arbitrary and limitless actions.
\end{abstract}

\section{Keywords}

International Peace and Security, Security Council, Human Rights, Humanitarian 
Law, Terrorism, Weapons of Mass Destruction

\section{Introduction}

The ultimate goal of human during history in all societies is to achieve such peace and security that as a result violence of human life disappeared, and the dignity of man restores its place. From a long time ago, the thought of freedom from strife and war has been equaled to peace. However, war as a country foreign policy tool has formed part of human existence and simultaneously, most is looking for ways to save mankind from this disaster.

According to the United Nations Charter UN began with the decision to protect future generations from the war disasters. Meanwhile, maintaining international peace and security were considered as the first target. According to Article 24 of the Charter, United Nations members gave it to Security Council and agreed that the Security Council perform its duties behalf of members (Malone, 2008). UN Security Council as the custodian of international peace and security during its life witnessed numerous developments in the international system that naturally have been effective in this important international body functioning, so this study was to investigate the role of the security Council in the unofficial fundamental change in the concept of international peace and security beyond the traditional concept of political and economic measures which is stipulated in the Charter (Tsagourias, 2011).

\section{The New Definition of Peace}

Perhaps the most serious and the most important part in peace operations is linked to the definition of peace. In other words, assessment and analysis in the peace context of the operational require the understanding approaches related to definition and explanation of this universal value content. Because of the diverse and different definitions and explanations of this value, has become a category for the processes, security and political legal doctrines, and discourse deployment of them against each other as well. This notion not only shows the freshened substrates of anti-peace phenomena, but determines the measures and requirements which are worthy of support in peace refuge and as well as many other concepts there is no general agreement about it. Thus knowing peace is related to precondition of any curiosity about finding good peace and distinguishing it from a bad peace and other concepts. Due to the different position of Peace in various fields is, different concepts depending on each of these has been mentioned. It is thought the most important thing is that whether peace should simply be defined as the absence of war and direct violence (negative peace), or whether it involves both mean of absence of war and direct violence in the presence of social justice (positive peace) (Kurtz, 1999). In the second sense, peace is political conditions that guarantee social justice and stability through institutions, procedures and the formal and non-formal norms (Miller, 2005). In the etymological meaning, peace means are as follows:

- State which is prevailing in the absence of a war, 
- Treaty after the war,

- State of harmony and balance (Free Collins Dictionaries),

- The silence and calmness state.

Traditional thinking to peace was directed only to avoid the war and because of being unaware of the peace removing ongoing process based on social and economic inequalities, it was never successful. Traditional Peace is not only compelled to maintain the status quo, but counts on same goal and it is natural that such a view to the preservation of unequal conditions, will not make peace universal and will not share to everyone. It can not be expected from the traditional peace instead of calming down inflamed condition. Although with the conceptual frameworks are called as comprehensive peace, Sustainable situation will not exist, although it is called eternal peace.

By the traditional thinking receding, new thinking experts know peace as representing situation in which all human beings are endowed with real human dignity and human life. This means that people, regardless of creed, race and etc. be able to live with having relative prosperity, education, health, employment, equality before the law, free elections and etc. and be safe to speak their minds without. In this context, any agent or biological factors expose these components to damage, are threatening to peace (Vankovska \& Wiberg, 2002).

\section{The Status of International Peace and Security in the Charter of the United Nations}

The failure of the League of Nations in the prevention of World War II, in the belief that the creation of an efficient system of international cooperation can be effective in protecting the world against the war did not create doubt. U.N in accordance with the Charter of the United Nations, began with decision to protect future generations from the ravages of war. The maintenance of peace and international security was considered as the first target. Although the peace is one of the oldest human aspirations, human history is full of conflicts, contradictions and collisions. Two devastating and damaging wars in the short distance of each other, in the first half of the twentieth century, shook the international community and public opinion and caused politicians and lawyers attempted to find a way to reduce the threats to peace in the international community. Earlier it was mentioned that the peace in Classic concept is a condition where there is no war. Before the founding of the United Nations Peace in the international system had the same concept but UN Charter has broadens its concept and considered as "an international order institution based on justice". So in the current perspective, no longer merely lack of war does not mean peace establishment and Continuity, but anything that conflicts with justice, may be threatening for the peace and violate it (Ashra'fi, 2015).

In 1945, when world leaders gathered in San Francisco to form the United Nations, their minds was mainly on international peace and security. In fact, the first line of the introduction of the Charter points out the need to preserve future generations from the dangers of war. To achieve this goal, the founders of the organization, awarded the power of collective security system to maintain peace and international security to U.N. In this system, aggression against a member state is seen as aggression against all. These 
executive powers are concentrated in the Security Council. The most important reason of forming, the existence purpose and goal of United Nations, to maintain international peace and security. This purpose is stated in paragraph 1 of Article 1 . Of course outlined goals in 2, 3 and 4 paragraphs are also somehow related to international peace and security and their realization is supplies this goal. The goal of the Charter clearly was to prevent war and maintain peace in the negative sense. For this purpose, 2 (4) Article of the Charter prohibits the threat of force or use of force and has been entrusted collective security organization to the Security Council. It should be noted that The Charter contains seemingly conflicting and contradictory articles. On the one hand in the first part of Article (1) and in a predicted manner in Chapter VII, knows his mission to preserve the status quo. On the other hand, in 2 and 3 paragraphs of Article 1 and Article 55 of the Charter and some other articles, world desirable change through the development of friendly relations among nations and international cooperation in the economic, social, humanitarian and etc. has been considered. According to the UN Charter the use of force is possible only in two ways: one on the implementation of the collective security system in cases that peace is threatened, or aggression action has been done and the other in self-defense. In this way government individual resort of force is only possible in self-defense, not to prosecute or justice concept (Shaygan, 2002).

United nations charter article 10, paragraphs 3, 2 states strengthen international peace through development of friendly relations that reduce the underlying causes of war and world peace Consolidation. As the provisions of Articles 33, 34, 36, 39 and 50 Article of the Charter, the goal is attainment of these objectives through peaceful means. According to Article 24 of the Charter, the United Nations members handed international peace and security over to the Security Council and agreed that the Security Council takes action that is responsible for behalf of members. UN Security Council as the custodian of international peace and security during his lifetime has seen several developments in the international system that has naturally been effective in functioning of this important international institution. Security Council was largely powerless in the international crisis during the Cold War and rivalry between the two superpowers of East and West and for multiple use of the veto and thus this increase the activities of the General Assembly and the typical case was United resolution approval for Peace in the field of international peace and security maintaining under which the General Assembly is empowered to convene within 24 hours and apply measures to deal with violations (Soltani, 2005).

\section{The Definition of Peace, Threaten or Violation in the Charter}

With a view to the UN Charter, we find that nowhere in the Charter, there is not any definition of peace or breach of the peace or a threat to international peace and securi$t y^{1}$. Is this lack of definition and presentation of objective criteria associated with peace

${ }^{1}$ Of course, secretary general supreme board report under the title of "A more secure world, our shared responsibility" that was awarded to the secretary general on Sept. 22, 2004, has offered a definition against international security that according to it threatening against international security or out of border threatening, there are threatening connected to each other that attacking to one, is considered, the attack to all thus the base of threaten against international security expends the danger of other threats: $A$ More Secure World: Our Shared Responsibility: The Report is Available: http://www.un.org/secureworld/report.pdf. 
and international security maintaining in terms of the nature of international peace and security and or the main reason should be found in the context of the international community. It seems that the main reason of lack of determination of the boundaries of the concept of international peace and security should be searched in the structure of the international community (Henderson \& Lubell, 2013). The structure of the United Nations, especially the Security Council reflects the international structure and power relationship during the foundation of the organization and the years following it. In fact, fear that the two world wars had created in the world public opinion; put the need to maintain international peace and security in head of other international needs. So that San Francisco conference participants are forced to accept broad powers of Security Council in Authentication of a threat to peace and its permanent member special privilege and veto right in a way that was outlined in the Dumbarton proposals.

So it seems the lack of definition for the concepts of peace, or threatens or peace breach in the Charter of the United Nations was deliberate and the founders of the Charter have given judging the occurrence or the amplitude of each of these concepts to the Security Council. This technique allows flexibility on the one hand and adapt to changing conditions when the international organization provides and on the other to allow the Security Council is due to new developments in the world, the sense of peace and international security (Bruno, 2012).

\section{New Threats and Challenges Confronting International Peace and Security}

Since the beginning of the United Nations was with the aim of preventing ruinous wars like World Wars I and II, the governments understating of breach of peace and international security can be known as emergence of a situation that the world will be facing similar events. Hence the most effort of origination to end the 80 s was to prevent the development of disputes between states, limiting the scope of the war and the threat of weapons of mass destruction. But after the collapse of the Soviet Union and the perspective transformation of this imperial heirs to international system and the gradual transformation in some of the concepts related to peace and security and members collaboration enhancement, the United Nations focused on the more general field of governments direct war (Williams, 2008). According tasks that United Nations Charter considered for each of the pillars of the United Nations, primary responsibility for maintaining international peace and security is entrusted to Security Council which in this case has general jurisdiction. UN Security Council for doing its tasks requires tools that were put at the disposal of the Council in the sixth and seventh seasons Charter of the United Nations (Mousazadeh, 2012).

By studying the performance of the Security Council as custodian of international peace and security in recent years suggest a broad interpretation of this pillar of concept of international peace and security or peace threatening. The UN Security Council adopted a statement on 31 January 1992 and reiterated in the statement that a lack of inter-state conflict alone is not peace, but economic, social, humanitarian and environmental instability is a threat to peace and security ${ }^{2}$. The Declaration was the origin 
of the evolution of the concept of peace in the Security Council. What in The new era and the beginning of the third millennium is different from the past, first is the change in threshold of threat and breach of the peace. That is, peace is not necessarily opposed to the war but its realization requires a set of conditions associated with a healthy, quiet, safe and excellent lifestyle for human beings. Secondly subject area of benefited and committed has expanded in peace area that is the peace is not just an intergovernmental phenomenon but is inter-human and inter-group as well (Vakil, 2013).

Also international peace and security Threats and challenges texture is got out from traditional mode which was more military and in addition to it, political, economic, social and environmental threats caused international peace and security hazard (Ashra'fi, 2015). Civil War, violation of human rights, weapons of mass destruction development, organized crime, international terrorism, lack of democracy and government instability and poverty and underdevelopment, are included in the challenges and threats that have strong potential for growth and negatively affecting peace and international security. In the following we study some of international events and the Security Council performance according to the new concept of international peace and security (High-Level Panel, 2004).

\section{The Events of 11 September, the Milestone of Terrorism Consideration as a Threat to International Peace and Security}

Early morning hours Disaster of September 11 led to the collapse of two skyscrapers of the World Trade Center in New York and the destruction of Pentagon building in Washington, impressed global geopolitical gradual formation trend in 2001 wonderfully. Nearly 4000 persons of various nationalities died in the harmful crash and thousands of innocent and helpless were wounded and have been reintegrated. However, from the perspective of economic damages were estimated at $\$ 50$ billion, but also hundreds of billions of dollars consequential commercial bankruptcy should be added to this figure. From moral and psychological perspective, United States of America for the first time was met with apprehension and bitterness of war.

General Assembly one day after the September 11 terrorist attacks , on September 12, 2001 a resolution condemning the terrorist attacks on America called for international cooperation for the arrest and punishment of the organizers of the attacks on America and also to prevent terrorist acts and terrorism Eradication globally. The Security Council has issued two resolutions on the events that are significant in terms of innovation:

\subsection{Resolution ${ }^{3}$}

The resolution was issued on 12 September 2001 by the Security Council. In this unanimously resolution the Council condemned the terrorist attacks on America and sympathized with the victims, it considered the attack as a threat to international peace and security and recognizes the rejoin individual or collective for America (Resolution Introduction).

The second paragraph of the resolution wants all States to cooperate with each other ${ }^{3}$ SC/Res/1363/2001/30, July. 
to give perpetrators, organizers and sponsors of these attacks to justice. In the fourth paragraph of the resolution also asked the international community to increase efforts to prevent and prohibit acts of terrorism with the cooperation and full implementation of international anti-terrorist conventions and Security Council resolutions, and finally the fifth paragraph the Council has announced readiness to take the necessary steps in response to these attacks and to combat all forms of terrorism in accordance with its responsibilities under the United Nations.

\subsubsection{Resolution 4}

This resolution issued by the Security Council on 28 September 2001 that was second resolution on terrorism, following the events of September eleventh. The council by issuing the resolution constructed international anti-terrorist infrastructure along with some basic obligations on governments. This resolution that is the most important counter-terrorism resolution particularly in connection with the financing of terrorism has a great importance. So that the foundation of the next Security Council counterterrorism resolutions are adjusted based on this resolution and has always emphasized the implementation of the resolution. In the preface of the second resolution, this really is an extension of the first resolution, in addition to addressing these things as threatening for international peace and security and recognition of the right of individual or collective self-defense in accordance with the Charter, containing substantial tips, including:

- Stressed the need to combat terrorist acts that endanger international peace and security.

- Expressing concern about the spread of terrorist acts that are caused by intolerance or extremism in various regions of the world.

- Wants all governments to immediately cooperate to ban and prevent terrorist acts.

In connection with the above analysis we can say 1373 resolution actually completes 1378 Resolution and several points are noteworthy:

1) Terrorism has been considered as a phenomenon threatening international peace and security.

2) It considered individual or collective self-defense for governments.

3) Governments are required to cooperate and to monitor this cooperation a committee is formed and wants government to report their performance on the implementation of this resolution to committee.

4) Council puts an emphasis to take the next steps if necessary (Under article 41 and 42 of the Charter) (Nielsen, 2010).

Considering the above, it can be said that the two resolutions and especially 1373 Resolution, are most complete and comprehensive resolution which has been issued in relation to terrorism by the United Nations Security Council (Brown, 2003).

\section{The Convergence of International Peace and Security and the Proliferation of Weapons of Mass Destruction}

The spread of nuclear weapons, unconventional, mass murder on the eve of the third millennium, has faced the international community with serious concerns. Concern of 
spreading of these weapons, has raised fears of another world war that if occurs will not be comparable with previous wars. Especially in recent years increasing terrorist attacks around the world and concern of access of terrorists to such weapons and endanger the security of the people Even inside their homes has caused The international community becomes sensitive about monitoring and safety mechanisms toward the prevalence of these weapons and their controls (Laqueut, 1996).

Washington and New York cities Terrorist attacks put some of the topics including the prohibition and control of weapons of mass destruction, including chemical weapons, biological, nuclear and biological in top of the agenda of the international community program and put it as one of the serious, outstanding and significant international, regional and national contemporary concerns (Oostithuzen \& Wimshurts, 2004). Examples of the use of weapons of mass destruction against innocent people, including atomic bomb on Hiroshima and Nagasaki in 1945, use of weapons of mass destruction against civilians in Japan, the use of chemical weapons by Iraq in its war with Iran, Halabja civilians killing by the regime And reported 124 cases of nuclear smuggling in 1994 that has doubled compared to a year earlier, indicates that these weapons can be considered as a threat to international peace and security ${ }^{5}$. By the end of the Cold War, important developments in the field of disarmament and control of Arms control were done by the United Nations. This evolution is more as a result of the security environment after the Cold War and the extended interpretation of United Nations Charter in relation to peace and international security. Beginning of such a change was the Kuwait crisis in 1990. With Iraq's invasion to Kuwait and occupation of this country by Iraqi forces shortly Security Council condemned the Iraqi action and issued a resolution Successive calling for the withdrawal of Iraq from Kuwait. Following Iraq's refusal to comply with Security Council resolutions this council issued 678 Resolution and permitted military attack on the country and by attacking coalition forces, Kuwait became Free and country occupation was ended. .In the crisis over Kuwait, it became apparent that Iraq had a wide range of programs to develop weapons of mass destruction, especially nuclear weapons and has provided considerable success in this area. Meanwhile, the Iraqi was a member of Treaty and the International Atomic Energy Agency (IAEA) has overseen the activities of the country. The inability of IAEA inspection of all nuclear activities in Iraq, led the Security Council should itself took action, Therefore 687 Resolution passed in April 1991 ${ }^{6}$. Actually the Security Council under resolution which issued for Chapter VII of the Charter of the United Nations moved in the direction of the Iraq disarmament. In 1993, in the wake of North Korea's threat to leave the nuclear Non-proliferation treaty, passed 825 resolutions ${ }^{7}$. Following the nuclear tests by India and Pakistan in May 1998 by the 1172 resolution condemned $^{8}$ these experiments and in 8 Nov of the 2002 issued 1441 resolution on Iraq9.

\footnotetext{
${ }^{5}$ A Report of the United Nations Association of the United States of American the Security Council and Non-proliferation, comforting the proliferation Danger: The Rule of the U.N Security Council, 22 may 1995. ${ }^{6}$ Sc/Res/687/1991/3April.

${ }^{7} \mathrm{Sc} / \mathrm{Res} / 825 / 1993 / 11$ may.

${ }^{8} \mathrm{Sc} / \mathrm{Res} / 1172 / 1998 / 6$ Jun.

${ }^{9} \mathrm{Sc} / \mathrm{Res} / 1441 / 2002 / 8$ Nov.
} 


\section{Iran's Nuclear Issue and the Approach of the Security Council}

Board of Governors of the International Atomic Energy Agency on February 4, 2006 decided to send the case report nuclear activities of the Islamic Republic of Iran to the Security Council ${ }^{10}$. This action was performed after the March forum by the agency general secretary (IAEA, 2006). From then, along the International Atomic Energy Agency which already had monitor on Iran's nuclear program, The UN Security Council adopted decisions in this regard which in many aspects from the perspective of international law, is noticeable. After reception of IAEA Director, the Security Council put issue in its agenda and in the first step issued a presidential statement quickly. Argentinean Director of the Security Council announced reference position in relation to Iran's nuclear program in a statement on March 29, 2006 ${ }^{11}$. In this statement despite emphasizing the right of States Parties to the Non Proliferation Treaty (NPT) to use nuclear energy for peaceful purposes without discrimination, the Council expressed serious concern, asked Iran to take steps for requirements of Board of Governors in particular full and stable suspension of enrichment. Subsequently, according to lack of acceptance of Council demands contained in Security Council presidential statement by Iran, after the publication of the Council demanded report requested from the international atomic energy agency Director General, Security Council was adopted 1696 resolution on 31 July 2006 in accordance with Article 40 of the Charter. In this resolution, the Council stressed on agency previous resolutions and its former statements, along with a series of demands, notably asked from Iran to suspend all activities related to enrichment and Reprocessing. Council introduced this request with reference to $40 \mathrm{Ar}-$ ticle of the Charter of the United Nations with the goal to non-binding suspension. Failure to comply with resolutions 1737, 1747, 1803 and 1929 requests followed under article 41 that asked from Iran and other members of the United Nations to enforce certain sanctions And in fact Iran's nuclear activities was considered by the Council as a threat to international peace and security.

\section{Legal Review of Security Council Entering to Iran's Nuclear Program}

It is believed that generally sending Iran issue to the Security Council was too hasty because still peaceful means, such as conciliation, commission of inquiry, mediation, good offices and legal remedies such as arbitration and the International Court of Justice which is predicted in Charter of the United Nations have not been used (Kosha \& Eskandari, 2012). Some lawyers believe that on the basis of the Charter, the Security Council in its primary task to maintain international peace and security, has unlimited jurisdiction and could eventually ignore international law. Others believe that the Security Council is bounded based on the final part of a charter practice based on the principles of justice and international law. What is not disputed, there is specific responsibilities in relation to the powers of the Council which must comply with the fundamental principles of international law and the international. In other words, if the Security Council decision is inconsistent with the international principles and rules, it

${ }^{10}$ IAEA Doc. Resolution of Board of Governors, GOV/2006/14, 4 February 2006. Available at: http://www.iaea.org

${ }^{11}$ UN Doc. Statement by the President of the Security Council, S/PRST/2006/15, 29 March 2006. 
is discredited and the government can object to it.

However, in accordance with Article 24 of the Charter of the United Nations UN member are required to comply with the resolutions and decisions of the Security Council under Chapter VII of the Charter, According to Article 25 of the Charter states commitment to this depends on the Security Council action based on the principles of the Charter that in The view of number of lawyers According to the description, the principles of the Charter are not included about Security Council decisions on Iran (Kosha \& Eskandari, 2012).

\section{Crisis in Libya, the Security Council and the Responsibility to Protect}

With the start of the uprising against authoritarian regimes in North Africa and the Arab world unrest spread from Tunisia and Egypt to Libya in February 2011, the government of Muammar Gaddafi responsed violently and did brutal crackdown (Bellamy \& Williams, 2011). The severity of violence committed by the Gaddafi regime in the face of protesters and civilians have been attracted international attention (Reuters, 22 Feb, 2011) and finally by the rapid intervention of the Security Council in relation to the same crises, led to the collapse of Gaddafi's 42-year rule. The importance of this issue is that Libya case is the first critical that the Security Council based on the doctrine of responsibility to protect every government is responsible to protect their populations against war crimes, genocide, ethnic cleansing and crimes against humanity (Thakur, 2011). The Sovereignty essential nature has changed from the regime privileges and immunities of the responsibility to protect people against brutal crimes; so if the government fails in its responsibility, the responsibility of the international community will be achieved through UN structures and procedures (Bellamy \& Williams, 2011).

The Security Council in The first step in 1970 consensus resolution ${ }^{12}$ in 26 February 2011 explicitly emphasize on the "responsibility to protect" the Libyan government about its population and adopt a series of civilian actions and of course Punitive. Diplomatic measures, asset freezes, travel bans, arms embargo, suspending Libya's membership in some international and regional institutions and referral of Libya to the International Criminal Court, were Among these proceedings. This process leads to resolution 1973 (with 10 votes in favor and 5 abstentions) of Security Council based on nofly zone on March 17, 2011, which led to the use of military force to protect the civilian population in Libya ${ }^{13}$. The resolution condemning violence in Libya again and explicitly emphasized on the "responsibility" of the government of Libya in "support" of its population. operations in Libya In addition to running no-fly zone, was to protect civilian population and also threatened areas and while the participants with justification for this purpose, have targeted pro-Gaddafi forces in the numerous air strikes Which eventually led to the fall of the Gaddafi regime and the revolution in Libya.

Libya crisis that triggered international intervention in the country based on the doctrine of responsibility to protect, Showed that in case of a consensus, or at least lack of opposition to international human rights norms Not only an international context

${ }^{12} \mathrm{Sc} / \mathrm{Res} / 1970 / 2011 / 26$ Feb.

${ }^{13} \mathrm{Sc} / \mathrm{Res} / 1973 / 2011 / 17$ March. 
exists to support people in situations where the government is not able to fulfill their responsibility to the people, but U.N and at the head of the it the security Council can act effectively in this regard (Bellamy \& Williams, 2011). The Libyan crisis practically highlighted the importance of the responsibility to protect doctrine and predisposing to turn it into an international norm. Genesis of the doctrine of responsibility to protect could underlie international peace and security with respect for human rights and international humanitarian law. The application of this doctrine in Darfur and Libya with a focus on the Security Council and with other international and regional bodies cooperation All suggest increasing the credibility, legitimacy of responsibility to protect and a basis for consolidation it as a international norm.

\section{Conclusion}

In this study, the expression of the traditional concept of peace as well as peace in the modern sense of the international community, the role and actions of the Security Council in the evolution of this concept are studied. The council during cold war due to the competition between two East and West superpowers has shown largely powerless in the face of international crises. The end of the Cold War and the collapse of East Camp Council have provided a new opportunity for Security Council to take a new approach to the analysis of international events and take action. It is said that the traditional concept of peace, which is solely confined to the absence of conflict between the parties extended interoperation by the Security Council has changed to the today sense that even contains bad economic situation and environmental risks. In this way, resolutions and actions of the Security Council under the Charter of the United Nations that occurred by recognizing the events issued as a threat to the peace and security situation, Have a significant impact on the evolution of the concept. To prove this, the present study explores some events, such as the events of September eleven, referring the Iranian nuclear issue to the security Council as well as the performance of the Council in the cases of Iraq and Bosnia that develop decisions of the council on the crisis and recognize them as a threat to international peace and security the same measures in same events of peace concept to what is today among jurists. This has gone so far that in some cases of problem a proper legal status can be found for Security Council action based on the provisions of the Charter and somehow has become a legislator on a world stage. The most important areas that the Security Council develop international peace and security during the Cold War and the beginning of the millennium was Human rights and humanitarian violations, terrorism, proliferation of weapons of mass destruction and environmental issues. In any case, the development of Authority of the Security Council should be based on the Authority explicit and general interpretation of that pillar and in the framework of Charter principles. As a result, the Council is not legally able to do arbitrary and without any kind of restriction.

\section{References}

Ashra'fi, D. (2015). International Organizations and the Conceptual Evolution of National Sovereignty. Tehran: Khorsandy Pub.

Bellamy, A. J., \& Williams, P. D. (2011). The New Politics of Protection? Cote d'Ivoire, Libya and 
Responsibility to Protect. International Affairs, 87, 825-850. https://doi.org/10.1111/j.1468-2346.2011.01006.x

Brown, D. (2003). Use of Force against Terrorism after September 11: State Responsibility, SelfDefence and Other Responses. Cardozo Journal of International and Comperative Law, 11.

Bruno, S. (2012). The Charter of United Nations: A Commentary. Oxford, New York: Oxford University Press.

Free Collins Dictionaries Online. http://www.collinslanguage.com

Henderson, C., \& Lubell, N. (2013). The Contemporary Legal Nature of UN Security Council Ceasefire Resolutions. Leiden Journal of International Law, 26, 369-397. https://doi.org/10.1017/S0922156513000083

High-Level Panel on Threats (2004). Challenges and Change, A More Secure World: Our Shared Responsibility. New York, Part B, Synopsis. http://www.un.org/en/peacebuilding/pdf/historical/hlp more secure world.pdf

IAEA Doc. Resolution of Board of Governors, GOV/2006/14, 4 February 2006. http://www.iaea.org/Publication/Documents/board/2006/gov2006-14.pdf

Kosha, S., \& Eskandari, M. A. (2012). Legal Challenges of the Referral of Iran's Nuclear File to the Security Council and sanction Resolutions, Tehran. Journal of Foreign Policy, 26, No. 2.

Kurtz, R. L. (1999). Encyclopedia of Violence, Peace, \& Conflict. San Diego, CA: Academic Press. Laqueut, W. (1996). Postmodern Terrorism. Foreign Affairs, 75, No. 50 Sep/Oct.

Malone, D. M. (2008). Security Council, in the Oxford Handbook on the United Nations, Ed.

Miller, C. A. (2005). A Glossary of terms and Concepts in Peace and Conflict Studies. Ciudad Colón: University for Peace.

Mousazadeh, R. (2012). The Law of International Organizations: The Security Council Law. Tehran: Mizan Legal Foundation.

Nielsen, E. (2010). State Responsibility for Terrorist Groups. Davis Journal International Law, 17.

Oostithuzen, G., \& Willmshorts, E. (2004). Terrorism and Weapons of Mass Destrruction: United Nations Security Council Resolution 1540, Chatham House BP 04/01, September, 2. http://www.riia.org

Shaygan, F. (2002). The United Nations Security Council and Concept of International Peace and Security. Tehran: Tehran University Pub.

Soltani, R. (2005). Security Council in the Beginning of Third Millennium (pp. 2-20). M.A. Thesis on International Law, Iran: Razavi University.

Thakur, R. (2011). Libya and Responsibility to Protect: Between Opportunistic Humanitarianism and Value-free Pragmatism. Security Challenges, 7, 13-25.

Tsagourias, N. (2011). Security Council Legislation Article 2(7) of the UN Charter and the Principle of Subsidiarity. Working Papers Series 05. Glasgow: Adam Smith Research Foundation

Vakil, A. S. (2013). Human Rights: International Peace and Security. Tehran: Majd Pub.

Vankovska, B., \& Wiberg, H. (2002). Between Past and Future: Civil-Military Relations in PostCommunist Balkan States (p. 17). I.B. Tauris.

Williams, J. (2008). New Approaches in Changing World: The Human Security Agenda. In: Banning Landmines (p. 284). UK: Roman and Littlefield Publisher, INC. 
Submit or recommend next manuscript to SCIRP and we will provide best service for you:

Accepting pre-submission inquiries through Email, Facebook, LinkedIn, Twitter, etc. A wide selection of journals (inclusive of 9 subjects, more than 200 journals) Providing 24-hour high-quality service

User-friendly online submission system

Fair and swift peer-review system

Efficient typesetting and proofreading procedure

Display of the result of downloads and visits, as well as the number of cited articles Maximum dissemination of your research work

Submit your manuscript at: http://papersubmission.scirp.org/

Or contact ojps@scirp.org 